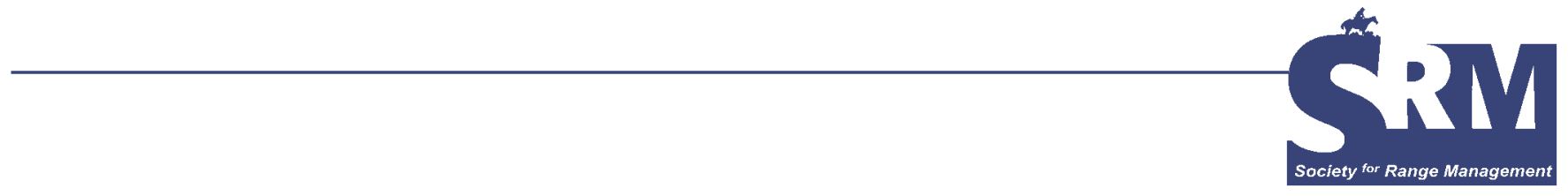

\title{
Sustainability: Giving and Receiving
}

\section{The eyes of a starving child.}

\section{By Thad Box}

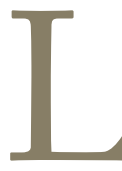

ooking into the eyes of a starving child was a rare gift I did not expect. His dull stare expanded my concept of sustainability. I thought anew about how land is used in different cultures, different economic systems, different population densities. I had to reexamine the connection between people and land.

Some 40 years ago I was the range person on a United Nations Development Program team to Somalia. Our instructions were to evaluate livestock production on the Horn of Africa following a major drought-a straightforward agricultural mission.

I looked forward to the assignment. I had watched the drought of the 1950s destroy my family's livelihood. I suffered from the devastating effects of 7 years of inadequate rainfall. One of America's most severe modern droughts turned me from an aspiring rancher into a schoolteacher.

I had appropriate academic degrees. I worked with some of the best range people in America. I studied and conducted research on the effects-biological and economic - of drought on plants, wildlife, and domestic animals. I thought I was ready for Africa.

I expected the dry, barren landscape, the blowing dust. I was shocked by dead cattle around drying water holes, their mummified carcasses scattered like alien sculptures on a Martian landscape. I was totally unprepared for the children at the first nomad camp we visited.

\footnotetext{
This article has been peer reviewed.
}

I'd seen pictures of children who looked like little skeletons covered by parched rawhide-bellies enlarged, eyes sunken. I didn't expect real children, looking as if they stepped from those pictures, to be waiting in the shade of an acacia tree.

I approached a little boy of about 6 , the age of my well-fed son waiting back in Texas. I knew no language the boy could understand. Maybe he would understand my smile as an offer to help. He stood stoic, almost in a stupor.

Our eyes met. I knew then that my job in Africa was not about livestock. It was not about grass and cows. It was about land and people who depend on it. My role was to apply carrying-capacity concepts to balance people and the land. It was to keep the human habitat sustainable.

Soon after we arrived in Somalia, the rains came. The landscape turned green. Seeds sprouted. Herbaceous carpets covered the land. New leaves appeared on shrubs. Milk flow increased in lactating camels. Surviving goats and sheep shed dry hair. I had seen livestock regain life after hard winters in Texas. I had never seen that occur in humans.

I watched the greening landscape renew vigor of people whose language and culture were foreign to me. Human nutrition improved, beginning with camel's milk, then supplemented by plants and animals. People's skin shed drought scales and became shiny. Adults regained a spring in their step. Children laughed once again. I witnessed a land-people connection in one of its most basic forms. People lived off their animals which in turn lived off the land.

We were sent to evaluate livestock. The real problem was to determine what human populations could be sustained in 
a simple, largely climatically controlled, system. Alternatively we could suggest more complex systems with social and economic modifications that might sustain increased human densities. Either way, it was a people carrying-capacity problem, not a range livestock exercise.

I grew up in a simple system. I never went hungry as a child. But some of my Great Depression generation, especially those living in cities, did not have enough to eat. We lived close to the land. But our system was more complex economically, politically, and socially than that of the Somalis.

We raised corn, beans, fruit, and fresh vegetables. We kept chickens, hogs, sheep, goats, and cattle. We ate much of what we raised, sold our surplus, and raised a cash crop for money to buy those things we could not get directly from the land. As the Depression progressed, prices dropped, markets faltered. Industry could not provide jobs. Banks failed.

The drought of the 1930s exacerbated economic conditions. Many people went hungry. Most of us on the land had enough to eat. We were money poor. Our system could not respond once the rains came.

Economic and political action brought the complex web of humans back into harmony with the land. People were removed from the land with make-work programs. They built roads, dams, and infrastructure to usher in a wage-based survival system. In the process, human population density was reduced in rural areas and increased in towns and cities.

Now, just a half century later, we have a new world order where rapid movement of goods and people allow a global market. We no longer depend on land immediately around us for sustenance. I eat apples from trees in my backyard. I also eat apples with little stickers that tell me they are from Washington State, New Zealand, Chile, or China.

Children in industrialized nations may have access to nutritious food that provides healthy bodies, but those children often develop social or psychological disorders. Richard Louv, in his book, The Last Child Left in the Woods, talks about a "nature deficit disorder." Studies show many childhood diseases-obesity, diabetes, psychological problems, behavioral disorders - may be caused from lack of contact with the land.

Each year a smaller percentage of the human population actually works the land. In the United States less than $2 \%$ of the people produce food for the rest of us. A declining number of people worldwide see or feel any relationship with the land.

This issue of Rangelands examines "Gifts from the land/ gifts to the land." In a global economy, we take land for granted. We accept its gifts, often attributing them to the free market or our own entrepreneurial skill. We seldom recognize land's gift of renewal.

Traditionally, our gift to the land has been improving management practices on ranches or other discreet land areas. Goods were produced while land was protected. In return, the land provided good things we called gifts that made our life more enjoyable, more productive.

In the global economy, there are few opportunities to practice that role of our profession. We must look for new

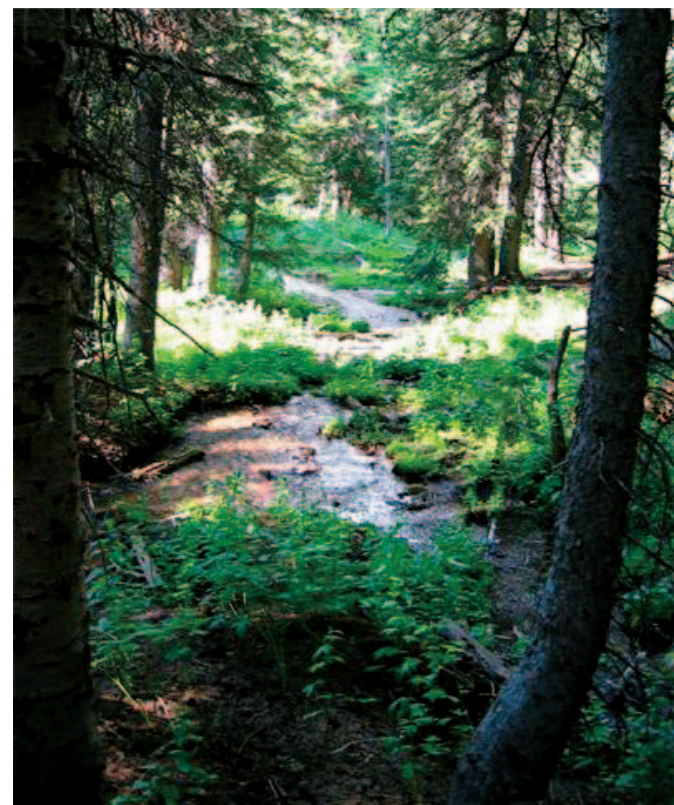

Where the spirit heals.

ways to give to the land. And we must learn to recognize gifts from the land that may not be identified with land in our own backyard. Our main goal may be to instill a land ethic in the billions of people whose urban lifestyles deny them contact with the land.

\section{Land Ethic, Our Gift to the Land}

Our real and lasting gift may be in our living a land ethic that insures healthy and sustainable communities, including transferring our values to the next generation. Such other gifts of stewardship - proper management, control of harmful influences - are but subheadings of developing an ethic for sustainability.

My working definition of a land ethic is that land does not belong to us; we belong to the land. No one can deny that the Somali boy under the acacia tree was a product, or victim, of the land. He did not control the system, it controlled him. In such a system reverence, even worship, of the controlling agent is a way of appeasing a controller god. Some aboriginal societies talk of "earth being a mother who feeds us." Others make offerings to gods of the earth.

My family did not own land in our slightly more complex system. We were tenant farmers. Land fed us. It, though legally owned by someone else, controlled us. We didn't worship land or an earth goddess. Our god was a superior power who made heaven and earth. He made us in his image, to have control over things. He made land, like horses, to be worked for our survival. But land controlled us whereas legal, economic, and political issues muddled our simple system.

Ralph Waldo Emerson spoke beautifully to the land ethic in his earth-song within his poem "Hamatreya:"

"They called me theirs

Who so controlled me: 
Yet every one

Wished to stay, and is gone,

How am I theirs,

if they cannot bold me,

but I hold them."

Aldo Leopold gave an expanded version of the land ethic in Sand County Almanac. Most conservationists accept it:

"All ethics so far evolved rest upon a single premise that the individual is a member of a community of interdependent parts. His instincts prompt him to compete for a place in that community, but his ethics prompt him to also co-operate (perhaps in order that there may be a place to compete for).... The land ethic simply enlarges the boundaries of the community to include soils, waters, plants, and animals, or collectively: the land."

Leopold's ethic makes us as part of the land. The main point is this:

"In short, a land ethic changes the role of Homo sapiens from conqueror of the land-community to plain member and citizen of it. It implies respect for his fellow members, and also respect for the community as such."

Conservationists of my generation built their careers and their lives around this concept that demoted humans from god-appointed controllers of land to citizens of it. We did not worship land (though some people made gods of its "gifts": white-faced cows, five-point bull elks, 1000-barrel-a-day oil wells, white-water rapids, wilderness sunsets, feisty trout.)

We paid lip service to being part of a biological system.

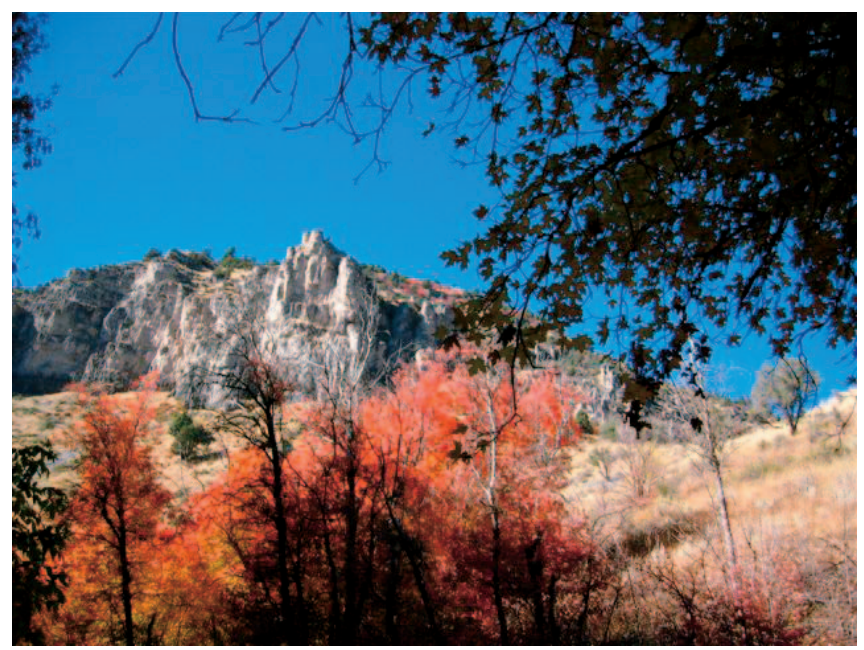

Where the big bucks hide.

But we were the thinking members who had a corner on intelligence (or so we thought). We had command of technology. As such, we sought to redirect land toward a more comfortable and enjoyable life for our species.

From our elevated opinion of our role as a special "plain member and citizen" we developed practices of multiple use, sacrifice areas, reclaiming land, supplementing fertility, transporting water-the list goes on. We couched our land

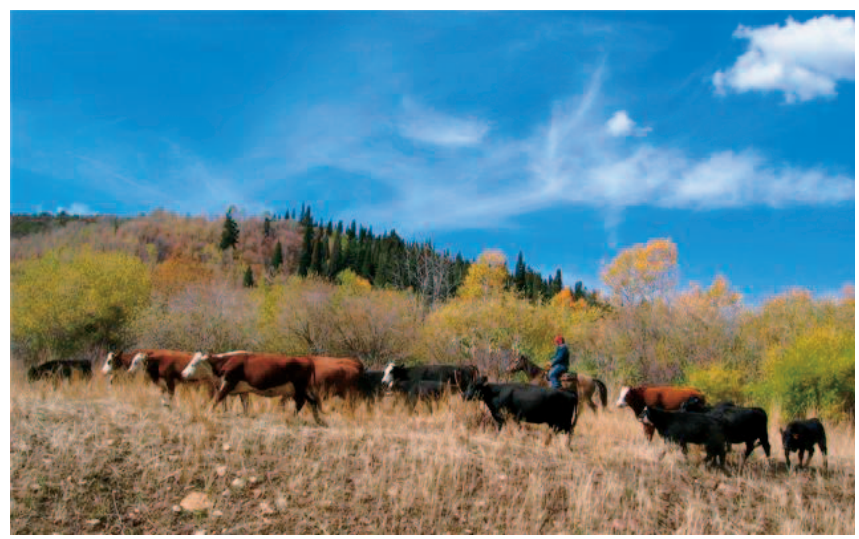

Coming off the summer range.

policies on a land ethic but did not implement it fully because our new "member" status took a back seat to our perceived god-appointed role.

Instead of managing land for a finite carrying capacity, we justified our actions to increase human populations by claiming we were superior beings favored by god. He would approve of our making the community carry a larger number of our kind. And we did it knowing, full well, that in an interrelated system one species expands beyond its natural biological carrying capacity only at the expense of other species.

It is easy to see land is an interrelated community of which we are a part if the system is as simple as the Somali examples The interrelationships are visible in a farm or even a ranch. It works fairly well with political subdivisions that are created with simple, direct goals — such as soil and water conservation districts. In those we can see that interactions and connections lead to a more stable and prosperous group. But in larger political groupings, even those as small as counties, the concept of our being citizens of the land may be obscured by the complexity of economic and political forces.

In the global economy it is near impossible to show that one healthy ranch or one conservation district, functioning as an interconnected community, can have a positive effect on global populations. Instead, we demonstrate that collective actions of millions of people worldwide have an adverse effect on us. Negative examples divide us.

We collect hard scientific data that the world climate is warming, that carbon dioxide is rapidly increasing, and that human activity increases the amount of carbon dioxide. Yet some people ignore the science and argue that it is not human action but nature that causes global warming.

When doubts are expressed about such actions that have clear scientific proof, presenting a land ethic as science-based falls on deaf ears. In a skeptical global economy a land ethic becomes a moral issue. We have faith that the collective actions of people with a concern for land health makes the world better, better being defined as more likely to support sustainable lifestyles.

Our gift to the land is not just a list of things we have done to increase yield of various products. It is a pledge to apply our ethics to leave our world better than we found it. 


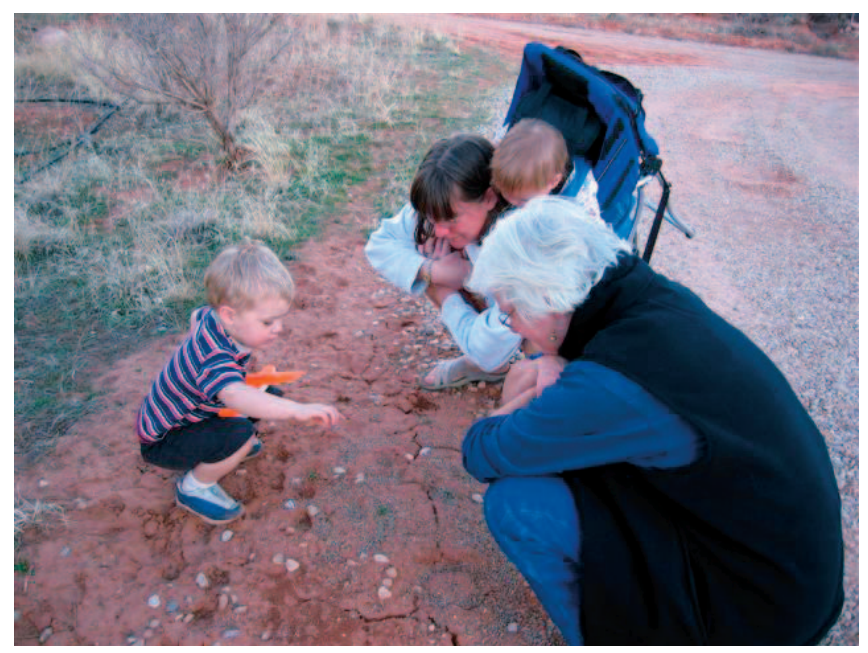

Three generations inspect little gifts from the land.

Our land ethic will survive only when our values, our genes, and our memes are passed to a new generation.

\section{Sustainability, Gift from the Land}

We accept food, fiber, fuel, relaxation, spiritual renewal as gifts from the land. But those gifts may be ephemeral. The real gift from the land is a promise of sustainability-the promise for a self-renewing system where our children and our children's children will have opportunities to develop their potential.

Sustainable systems have fairness and justice in the current generation. Those values are passed to the next generation through transgenerational mechanisms. Emphasis is on longterm stability over short-term gain. Each generation lives or dies on resources available to it. Mandates, debts, deficiencies, and burdens are not heaped upon future generations. Each generation arrives at conditions necessary for success. These simple characteristics of sustainable systems apply to an insect colony, a deer herd, a ranch, a country, a planet.

We learn rules for sustainability from our heroes, parents, and mentors. Earlier I wrote about Larry Stoddart taking my family up Logan Canyon. He took us to picnic places. We walked on trails where our son could toddle along after butterflies. He showed me fishing holes where I could teach my children to fish. He was not showing us a place. He gave us a gift of his spirit.

That spirit passed on to my children during outings in Logan Canyon. Now adults, those children regularly escape their urban jobs to float the San Juan River, camp on the Cache National Forest, or picnic in the dry stream bed of Australia's Todd River. I don't remember talking to my children about a land ethic. But they are teaching a land ethic to my grandchildren on a riverbank as I write.

Our heroes teach values as they work. We learn about sustainability through their spiritual tie to the land, their dedication to using science to make human conditions better, to make life more humane. Through them we learn renewal,

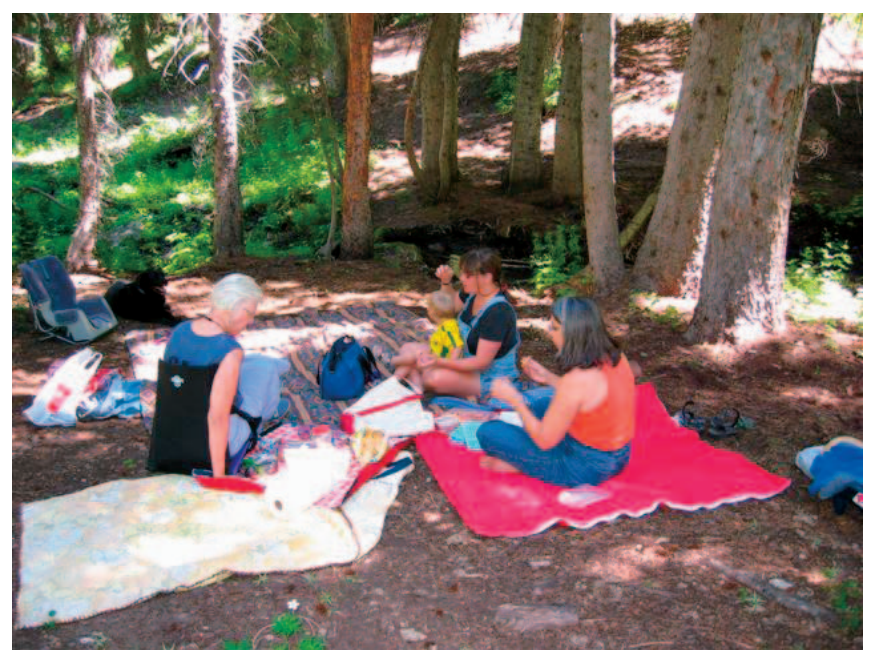

Sharing gifts from the land.

resurrection from the land.

It is through our demonstrating values and ethics that sustainability is passed to the next generation-not just to our children, but to all who observe our work, all who hear us talk, all who read our writings. We reach people who have little contact with the land by living our values, our land ethic.

Each time we approach a land use problem, we have a chance to teach, to demonstrate our ethic. We have many opportunities to correct land abuse. Noxious weeds invade rangeland. ATV trails form gullies. Farmland becomes housing developments. Pesticides poison hummingbirds. We live extravagantly. Land absorbs our insults. We humans are more fragile.

Earlier I wrote that unwarranted destruction of a land community is the moral equivalent of war. The spiritual connection between people and the land is lost. A shock and awe attack on a country or a sod-busting ATV cutting a new trail across rangeland makes conquering, not sustaining, the goal. Conquering of community, destroying its connectedness, diminishes the spirit of victor as well as victim. Whatever we do to the land community, we must not leave people suffering from posttraumatic stress syndrome.

Sustainability is about constant renewal. As a generation dies, the system is reborn, community is sustained by enduring principles and values. Our quest for sustainability is a moral journey. Our heroes blazed the path for us; we teach it to the next generation by the way we work, act, think.

The giants who trained me were firmly rooted in economic survival. They came of age in the Great Depression. A job and a meal were their goals. Aesthetics were a luxury. Riding a horse, making a sagebrush fire, cooking in a frying pan was their work, not their recreation. They spent their careers finding ways to make land produce more - more goods, more things, more income. They developed a land ethic as they worked the soil. A land ethic is our gift to the land. The promise of a good life for our grandkids - sustainability - is land's gift to us. 